\title{
Nutrient enrichment effect on macroinvertebrates in a lowland stream of Argentina
}

\author{
Agustina Cortelezzi 1,3, Carolina Ocón²,3, María V. López van Oosterom², \\ Rosana Cepeda' \& Alberto Rodrigues Capítulo2,3
}

\begin{abstract}
1. Instituto Multidisciplinario sobre Ecosistemas y Desarrollo Sustentable, UNCPBA, Paraje Arroyo Seco s/n, Tandil, Argentina. (aguscorte@gmail.com) 2. Instituto de Limnología Dr. Raúl A. Ringuelet (ILPLA), CCT La Plata - CONICET, UNLP, Bv. 120 s/n, La Plata, Argentina.

3. Consejo Nacional de Investigaciones Cientíicas y Técnicas (CONICET), Argentina.
\end{abstract}

\begin{abstract}
One of the most important effects derived from the intensive land use is the increase of nutrient concentration in the aquatic systems due to superficial drainage. Besides, the increment of precipitations in South America connected to the global climate change could intensify these anthropic impacts due to the changes in the runoff pattern and a greater discharge of water in the streams and rivers. The pampean streams are singular environments with high natural nutrient concentrations which could be increased even more if the predictions of global climate change for the area are met. In this context, the effect of experimental nutrient addition on macroinvertebrates in a lowland stream is studied. Samplings were carried out from March 2007 to February 2009 in two reaches (fertilized and unfertilized), upstream and downstream from the input of nutrients. The addition of nutrients caused an increase in the phosphorus concentration in the fertilized reach which was not observed for nitrogen concentration. From all macroinvertebrates studied only two taxa had significant differences in their abundance after fertilization: Corbicula fluminea and Ostracoda. Our results reveal that the disturbance caused by the increase of nutrients on the benthic community depends on basal nutrients concentration. The weak response of macroinvertebrates to fertilization in the pampean streams could be due to their tolerance to high concentrations of nutrients in relation to their evolutionary history in streams naturally enriched with nutrients. Further research concerning the thresholds of nutrients affecting macroinvertebrates and about the adaptive advantages of taxa in naturally eutrophic environments is still needed. This information will allow for a better understanding of the processes of nutrient cycling and for the construction of restoration measures in natural eutrophic ecosystems.
\end{abstract}

KEYWORDS. Phosphorus, nitrogen, fertilization, invertebrate abundance, climate change.

RESUMEN. Efecto del enriquecimiento de nutrientes en macroinvertebrados en un arroyo pampeano de Argentina. Uno de los efectos más importantes derivados del uso intensivo de la tierra es el aumento de la concentración de nutrientes en los sistemas acuáticos debido al escurrimiento superficial. Además, el incremento de las precipitaciones en América del Sur vinculado al cambio climático global podría intensificar estos impactos antrópicos debido a los cambios en los patrones de escurrimiento y una mayor descarga de agua en los arroyos y ríos. Los arroyos pampeanos son ambientes particulares, con altas concentraciones basales de nutrientes, que podrían incrementarse aún más si las predicciones del cambio climático global se cumplen. En este contexto, se estudió el efecto de la adición experimental de nutrientes en un arroyo pampeano sobre los macroinvertebrados. Los muestreos se llevaron a cabo entre marzo de 2007 y febrero de 2009 en dos tramos seleccionados, aguas arriba y aguas abajo de la entrada de nutrientes. La adición de nutrientes causó un aumento en la concentración de fósforo en el tramo fertilizado, lo que no se observó para la concentración de nitrógeno. De todos los macroinvertebrados estudiados sólo dos taxa tuvieron diferencias significativas en su abundancia después de la fertilización: Corbicula fluminea y ostrácodos. Nuestros resultados revelaron que la perturbación causada por el aumento de nutrientes en una comunidad bentónica depende de la concentración basal de nutrientes. La respuesta débil de macroinvertebrados a la fertilización en las corrientes pampeanas podría ser debido a su tolerancia a altas concentraciones de nutrientes de acuerdo a su historia evolutiva en arroyos enriquecidos naturalmente con nutrientes. Se necesitan nuevas investigaciones sobre los umbrales a partir de los cuales los macroinvertebrados podrían verse afectados y sobre las ventajas adaptativas de los taxones en ambientes eutróficos naturales. Esta información nos permitirá comprender mejor los procesos de reciclaje de nutrientes y así poder pensar medidas de restauración de ecosistemas eutróficos naturales.

PALABRAS CLAVE. Fósforo, nitrógeno, fertilización, abundancia de invertebrados, cambio climático.

Given that benthic macroinvertebrates represent an important fraction of stream biodiversity, they are frequently used as indicators in aquatic environments and their assemblage composition and richness exhibits a strong correlation with environmental change at reach and basin levels. However, while tolerance levels of a wide range of taxa have been established along gradients of organic pollution, little is known about how macroinvertebrates respond to elevated nutrient levels (FriBERG et al., 2010). While nutrient studies in lowland streams showed impacts on primary producers (ACUÑA et al., 2011) and on benthic microbial community (COCHERO et al., 2013), researches showing direct and indirect effects on higher trophic levels have been less conclusive due to the complexity of food webs that can buffer the potential transference of bottomup effects after nutrient addition (ARTIGAS et al., 2013).
Besides, most studies report changes in macroinvertebrates because the effect of increased nutrients has been conducted primarily in oligotrophic aquatic systems (BIGGs et al., 2000; ROBINSON \& GESSNER, 2000).

The pampean area of Buenos Aires Province (Argentina) holds the highest demographic and industrial concentration of the country, the greatest agriculture and livestock production as well as the most intense use of agrochemicals, as a result of the great expansion of agriculture in the last century (SALAZAR et al., 1996; GOMEZ $\&$ Rodrigues Capítulo, 2001). Because of such intensive human activity, many rivers and streams are impacted by diffuse pollution associated with crop cultivation and cattle raising (RodRIGUES CAPÍTULO et al., 2010). However, high nutrient levels have been reported for these streams even in sites with low or moderate cattle-raising and agriculture 
(FeIJoó et al., 1999; BAUER et al., 2002). The occurrence of high nutrient concentrations is characteristic of pampean streams (FeIJoó \& Lombardo, 2007). Indeed, nutrient levels in stream water show a relatively high concentration when compared with other lotic systems of the world (FeIJoó et al., 2014). Moreover, pampean streams can be classified as eutrophic when phosphorus is considered and as meso-eutrophic when nitrogen is taken into account (BARBOUR et al., 1999). This high natural nutrient loading of the Pampean streams, could be further increased if predictions of global climate change for the area are met. Thus, changes in the runoff patterns and a greater discharge of water in the streams and rivers (Hulme \& SHEARD, 1999) would lead to a greater input of nutrients, especially nitrogen and phosphorous, and contaminants into streams and rivers (Rodrigues CAPÍtulo et al., 2010; FerReiro et al., 2011). This situation may have harmful effects on the whole ecosystem with accompanying economic repercussions (DoDDs et al., 2009; ARTIGAS et al., 2013).

As part of the GlobRio project ("Global changes in river systems: effects on biodiversity, food web and system functioning") our main objective was to explore experimentally the effect of increased nutrient concentrations on the parameters of macroinvertebrate assemblages in a pampean stream. We also examined the temporal variability of the community descriptors over a study period. We hypothesized that density and dominance of macroinvertebrates would increase in the reach under nutrient enrichment while taxa richness would decrease.

\section{MATERIAL AND METHODS}

Study area. Pampean streams run through a vast grassy plain that shelters central Argentina, denominated the
Pampas. The pampean steppe is composed of gramineous grasses, which is the typical biome of the area (CABRERA, 1976). The climate is humid and temperate with a mean annual temperature of $20^{\circ} \mathrm{C}$ and a mean precipitation of $900 \mathrm{~mm} /$ year. La Choza stream is a $2^{\text {nd }}$ order stream located in the Pampas, Buenos Aires Province, Argentina (Fig. 1). Like most lotic systems of the region, it is characterized by a low slope $(<1 \%)$, a slow flow velocity, a high turbidity, abundant organic matter, and an elevated content of suspended solids (GIORGI et al., 2005). The streambed consists of fine sediments (primarily silt and clay) without stones or pebbles (FeIJoó et al., 2014). Besides, even in the upper-stream reaches, the absence of riparian vegetation, results in high levels of irradiance along the course, favoring the development of dense macrophyte stands and phitoperiphyton growth (FEIJoó \& LOMBARDO, 2007). Moreover, the heterogeneity of the pampean streams, resides not in the different types and sizes of the substrates present but rather in the diverse architecture of the aquatic plants which shelter a rich and dense invertebrate community (GIORGI et al., 2005).

La Choza watershed has a surface of 15,200 ha and features intense agricultural activity, with $64 \%$ of the area for cattle raising, 34\% for extensive agriculture, and the remaining $2 \%$ divided between poultry farming and different other urban uses (RodRigues CAPítulo et al., 2010).

Experimental design. Two reaches of $100 \mathrm{~m}$ in length were selected, the first site was located upstream (control site, named "C" in Fig. 1: $34^{\circ} 39^{\prime} 14^{\prime}$ "S, 59 $9^{\circ} 0^{\prime} 00^{\prime \prime} \mathrm{W}$ ), and the second downstream from the experimental input of nutrients (treatment site, named "T" in Fig. 1: $34^{\circ} 47^{\prime} 51$ "S, $\left.58^{\circ} 03^{\prime} 17^{\prime \prime} \mathrm{W}\right)$. The distance from the source is $2.5 \mathrm{~km}$ for control site and $7.5 \mathrm{~km}$ for the treatment site. Bimonthly
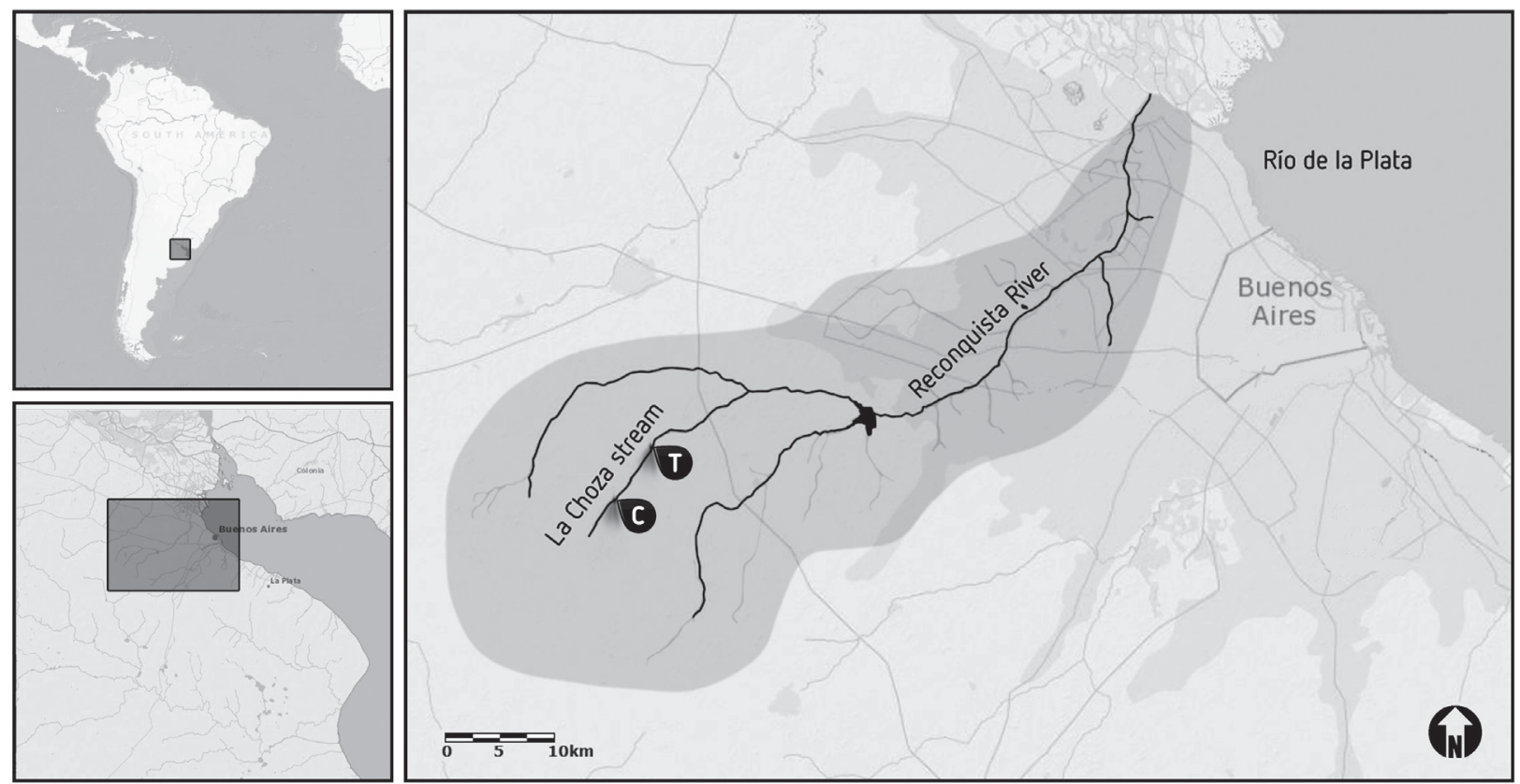

Fig. 1. Map of the study area showing La Choza stream, Buenos Aires Province, Argentina and the location of the sampling stations: control (C) and treatment $(\mathrm{T})$. 
samplings, from March 2007 through February 2009, took place at each site. On each sampling date the following physicochemical parameters were measured: temperature, $\mathrm{pH}$, conductivity, dissolved-oxygen level (DO) with a Hach HQ40d18 portable meter (Hach, Loveland, Colorado) and water samples $(250 \mathrm{ml})$ in triplicate were collected and filtered through glass-fiber filters of $0.7 \mu \mathrm{m}$ pore size (Whatman GF/F, Whatman International Ltd., Maidstone, England). The whole filtrate samples were analyzed for dissolved inorganic nitrogen (DIN) and soluble reactive phosphorus (SRP) by standard methods (APHA, 1998). The process of experimental fertilization initiated at the end of October 2007 and involved a continuous dissolution of nutrients at the treatment site of the stream. Due to the low water velocity, to obtain a homogeneous fertilization along the reach, nutrient additions consisted of mesh bags with $750 \mathrm{~g}$ of commercial fertilizer Compo Nitrofoska ${ }^{\circledR}(12 \%$ nitrogen, $12 \%$ phosphorus, $17 \%$ potassium), a mixture of frequent use in farming, and $250 \mathrm{~g}$ of urea. Twelve in-water bags were distributed along the treatment reach, and replaced 2 or 3 times a week during the fertilization period to maintain a constant fertilization rate (FeIJoó et al., 2014). Water samples in triplicate also were collected and analyzed during enrichment period every 5 to $10 \mathrm{~d}$ to better capture changes in nutrient concentrations (ARTIGAS et al., 2013).

Macroinvertebrate sampling. Macroinvertebrates were collected following RodRIGUES CAPítulo et al. (2009) and PlafKin et al. (1989). At each site, three replicates of benthic macroinvertebrates were collected with an Ekman grab $\left(100 \mathrm{~cm}^{2}\right)$. The samples were fixed in situ in $5 \%$ formaldehyde and the organisms sorted, identified and counted under a stereomicroscope following FERNÁNDEZ \& Domínguez (2001) taxonomic keys. The invertebrates were identified at the lowest possible level.

Data analysis. The physicochemical variables that may be affected by fertilization in the control and treatment sites were analyzed through descriptive statistics. In addition, macroinvertebrates density was described during the study period. Dominance index (Simpson), diversity (Shannon) and richness (such as number of taxa) were evaluated to describe the structure of the community at each site. The variation of these metrics on sites (spatial variation) and along the study (temporal variation) was tested by repeated measures ANOVA. We consider two situations: comparing the control and treatment site ( $\mathrm{C} 1 \mathrm{vs}$ T1) in 4 dates before fertilization and comparison between control and treatment in 6 dates after fertilization (C2 vs $\mathrm{T} 2)$.

Repeated measures ANOVA were also used to evaluate time and fertilization effect for the density of each taxon. Although this method is commonly used in experimental studies of nutrient fertilization, in our case it was not useful due to the taxa abundance showing a high variation between dates even before the start of fertilization. It is why we decided to use this information to perform a Student $t$ test. For each taxon the dates as independent replicates in two moments before (b) and after fertilization (a) were used. If the abundance taxa was statistically the same in treatment site and control site before fertilization between dates ( $p>0.05)$, and after fertilization this situation changed $(p<0.05)$, at that time the differences detected could be due to treatment. Similarly, if before treatment, the abundance was variable between sites $(p<0.05)$ and after the fertilization the abundances are similar $(p>0.05)$ that is, they stabilize; might it be an effect of fertilization. After this analysis, we described variations of the abundance of taxa that presented differences before and after fertilization using average graphs by date and sites. These values were presented on a logarithmic scale. Analyses were performed with InfoStat statistical software (Di RIENZo et al., 2008). We considered significative analyzes at $\mathrm{p}<0.05$.

\section{RESULTS}

The main physical and chemical characteristics of the sampling stations before and after fertilization of La Choza stream are shown in Table I. In general, conductivity, temperature and $\mathrm{pH}$ were similar before and after fertilization. The values of DO in both control and treatment sites remained stable, however after fertilization a decrease of this parameter was recorded in the treated site. The experimental fertilization increased the average SRP concentration by about 5 -fold in water column of treatment site above the natural value. However, the nutrient addition in treatment reach slightly altered the average DIN levels. At the beginning of fertilization a slight increase in the values of DIN was recorded which then decreased and remained low in the following samplings.

In the present study 25 taxa were identified, 23 of which were common to both sites, while the remaining 2 (Perithemis sp. and Belostoma sp.) were found only at the treatment site (Tab. II). In the control site, the total abundance was $70,345 \mathrm{ind} / \mathrm{m}^{2}$. In the treatment site, the total invertebrate abundance decreased from 181,466 to $100,722 \mathrm{ind} / \mathrm{m}^{2}$ after fertilization. In relation to community composition, the control site was dominated by Heleobia (25.3\%), Oligochaeta (21.8\%) and Chironomidae (19.3\%). In the treatment site, before fertilization, the community was dominated by oligochaetes (75.5\%), and after fertilization oligochaetes decreased their abundance $(37.2 \%)$, whereas Heleobia sp. (24.8\%) and chironomids (9.6\%) increased their representation resembling in composition to the control site.

Most of the metrics analyzed (Shannon, Simpson, and total density of macroinvertebrates) show a significant interaction between time and treatment but not between the site and time throughout the study. Metrics along sampling dates do not show the same performance in control and treatment sites, that is, there are no significant interaction between sites and time. There are significant differences between dates from the same site and between sites on the same date partitioning the study before and after fertilization. In the case of richness, the interaction also was 
Tab. I. Physicochemical parameters and nutrient concentration in the control and treatment reaches of La Choza stream, Buenos Aires Province, Argentina. Values are mean and standard deviations measured before and after fertilization.

\begin{tabular}{|c|c|c|c|c|}
\hline \multirow{2}{*}{ Parameters } & \multicolumn{2}{|c|}{ Control } & \multicolumn{2}{|c|}{ Treatment } \\
\hline & Before & After & Before & After \\
\hline Conductivity (uS/cm) & $866.66(511.8)$ & $1272.66(101.53)$ & $1748.44(500.62)$ & $1159.58(96.48)$ \\
\hline $\mathrm{T}^{\circ}\left({ }^{\circ} \mathrm{C}\right)$ & $13.97(7.88)$ & $19.99(7.57)$ & $13.84(6.01)$ & $19.22(8.31)$ \\
\hline $\mathrm{DO}(\mathrm{mg} / \mathrm{l})$ & $9.8(5.04)$ & $9.47(3.86)$ & $9.85(4.12)$ & $8.58(2.25)$ \\
\hline $\mathrm{pH}$ & $7.37(0.77)$ & $8.27(0.44)$ & $7.60(0.41)$ & $8.09(0.29)$ \\
\hline DIN (ug/l) & $650.75(435.21)$ & $925.72(1182.72)$ & $884.78(572.41)$ & $883.26(985.37)$ \\
\hline $\mathrm{SRP}(\mathrm{ug} / 1)$ & $205.62(178.96)$ & $93.47(25.41)$ & $247.59(136.59)$ & $431.60(246.08)$ \\
\hline
\end{tabular}

Tab. II. Mean density and standard deviation of the taxa present in La Choza stream, Buenos Aires Province, Argentina in control and treatment reaches.

\begin{tabular}{|c|c|c|c|}
\hline & \multirow{2}{*}{$\begin{array}{c}\text { Control } \\
(n=30)\end{array}$} & \multicolumn{2}{|c|}{ Treatment } \\
\hline & & Before $(n=12)$ & After $(n=18)$ \\
\hline Hirudinea & $570(242)$ & $142(50)$ & $494(284)$ \\
\hline Nematoda & $5232(1502)$ & $2150(1479)$ & $2106(532)$ \\
\hline Oligochaeta & $15304(4158)$ & $137094(84970)$ & 37517 (12729) \\
\hline Pomacea canaliculata & $68(20)$ & $33(26)$ & $172(92)$ \\
\hline Heleobia parchappei & $17814(5131)$ & $12983(4882)$ & $24944(4653)$ \\
\hline Hebetancylus moricardi & $276(108)$ & $233(143)$ & $161(84)$ \\
\hline Drepanotrema kermatoides & $118(111)$ & $167(104)$ & $6(6)$ \\
\hline Pisidium vile & $13(13)$ & $8(8)$ & $156(134)$ \\
\hline Pisidium sterkianum & $8350(4925)$ & $283(122)$ & $517(220)$ \\
\hline Corbicula fluminea & $360(333)$ & $219(98)$ & $6328(2123)$ \\
\hline Elmidae & $42(29)$ & $1636(815)$ & $2233(822)$ \\
\hline Hydrophilidae & $8(5)$ & 0 & $61(56)$ \\
\hline Coenagrionidae & $8(7)$ & $75(66)$ & $72(46)$ \\
\hline Perithemis sp. & 0 & $1633(868)$ & 0 \\
\hline Caenis sp. & 3541 (1104) & $1794(795)$ & $5133(1571)$ \\
\hline Americabaetis sp. & $12(8)$ & $242(166)$ & $161(155)$ \\
\hline Belostoma sp. & 0 & $7900(5631)$ & $267(267)$ \\
\hline Hyallela curvispina & $141(69)$ & $144(102)$ & $339(138)$ \\
\hline Aegla sp. & $3(3)$ & $50(42)$ & $56(27)$ \\
\hline Chironomidae & $13608(7765)$ & 9805 (5252) & $9650(3594)$ \\
\hline Ceratopogonidae & $1215(996)$ & $69(45)$ & $228(64)$ \\
\hline Ostracoda & $289(96)$ & $267(205)$ & $5861(1474)$ \\
\hline Cladocera & $1025(308)$ & $4233(2370)$ & $1067(594)$ \\
\hline Copepoda & $2111(642)$ & $136(75)$ & 3083 (1385) \\
\hline Acari & $237(222)$ & $167(104)$ & $111(52)$ \\
\hline
\end{tabular}

significant between time and treatment before treatment. However, after fertilization, richness was always higher in the sites treated than in the control site.

Although the general fertilization effects were weak, some specific invertebrate taxa were distinctly affected in abundance. Certain taxa such as Oligochaeta, Pomacea canaliculata, Hebetancylus moricandi, Pisidium sterkianum, Corbicula fluminea and Ostracoda showed significant differences in abundance at the sampling sites before and after fertilization (Tab. III). However, when comparing the control and treatment sites by dates, before and after fertilization, only Corbicula fluminea and Ostracoda showed an increase in abundance after fertilization (Fig. 2). For the rest of the taxa the differences could not be attributed to fertilization.

\section{DISCUSSION}

In this study, the experimental addition of phosphorus and nitrogen to a pampean stream caused the SRP concentration to be slightly higher in the fertilized reach, as expected, although this was not observed for DIN.
Tab. III. Results of the Student's t test for taxa abundance in the treatment reach site before (b) and after (a) fertilization, La Choza stream, Buenos Aires Province, Argentina.

\begin{tabular}{lcc}
\hline Taxa & Treatment & $p$ \\
\hline Oligochaeta & $b$ & 0.4963 \\
Pomacea canaliculata & $a$ & 0.0063 \\
& $b$ & 0.041 \\
Hebetancylus moricandi & $a$ & 0.444 \\
Pisidium sterkianum & $b$ & 0.037 \\
Corbicula fluminea & $a$ & 0.531 \\
Ostracoda & $b$ & 0.031 \\
& $a$ & $<0.0001$ \\
& $b$ & 0.492 \\
& $a$ & $<0.0001$ \\
& $b$ & 0.498 \\
\end{tabular}

The dissolved nitrogen added to the stream could have been either rapidly assimilated by algae, macrophytes, or bacteria, or could have left the system by denitrification processes caused by anaerobic bacteria in anoxic conditions (Cochero et al., 2013). According to Lin \& WeBster (2012) all these organisms can quickly take up nutrients from the water column and use these nutrients for production. 

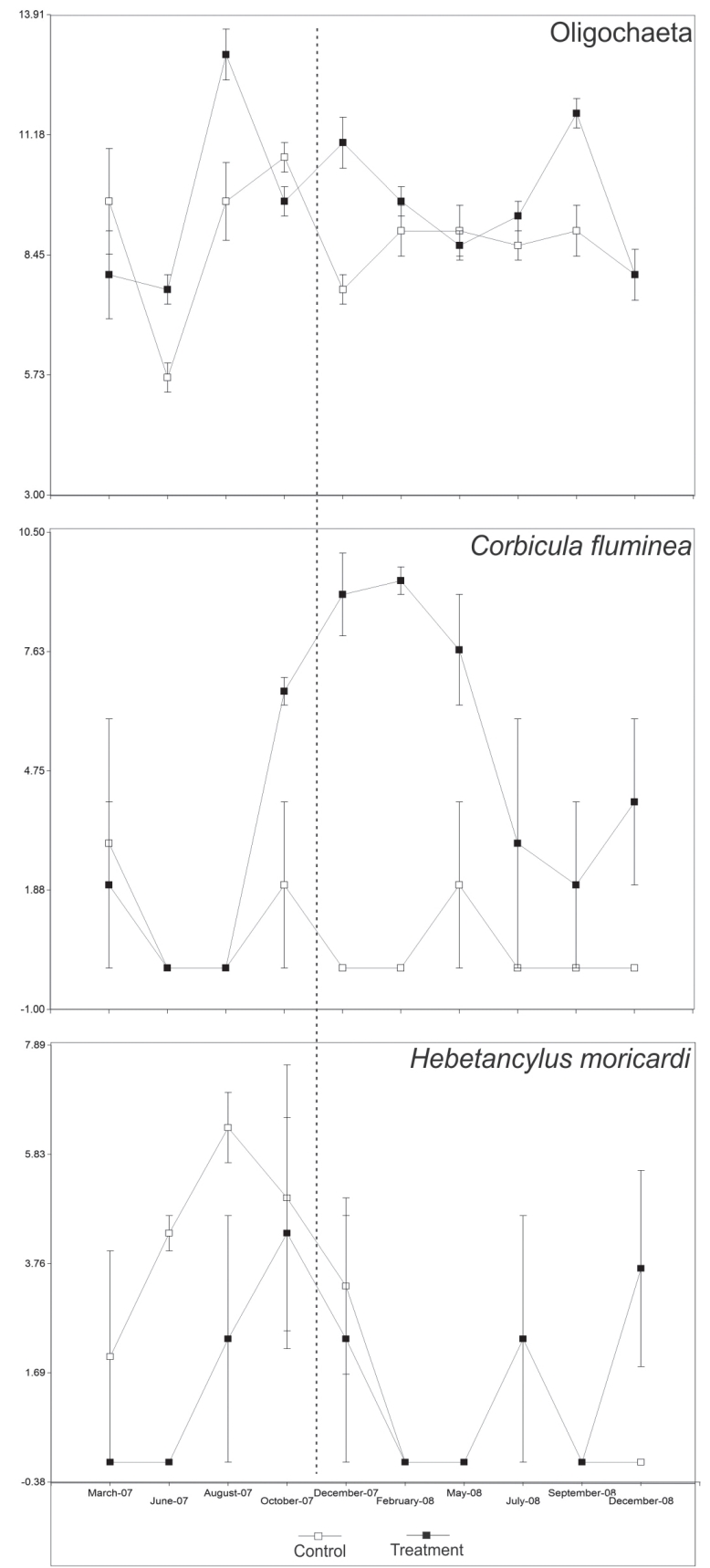
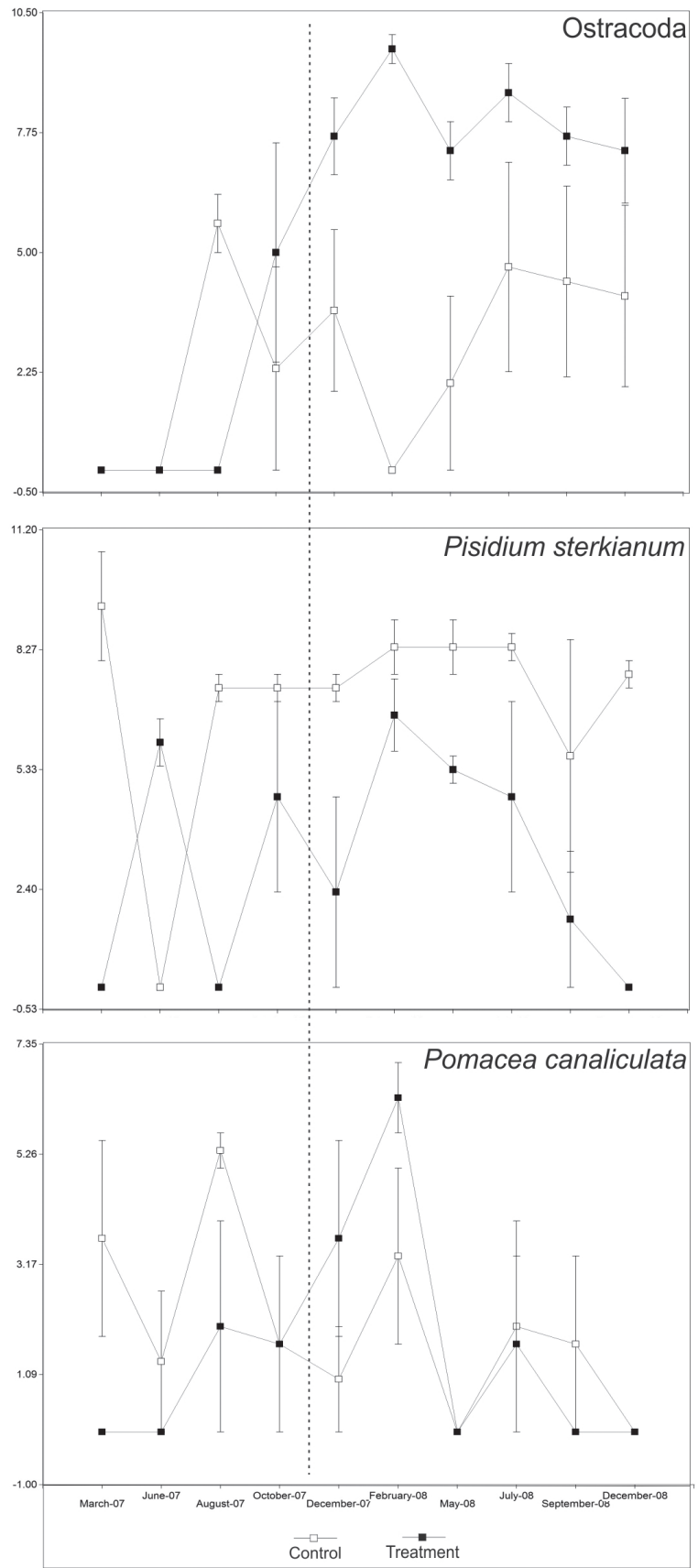

Fig. 2. Taxa abundance by date in control and treatment sites in La Choza stream, Buenos Aires Province, Argentina during 2007-2008.The dotted line indicates the time when fertilization begins.

In the two reaches studied, the invertebrate assemblage composition was similar although the abundance of taxa presents differences being lower in the control site. In the treatment site, the invertebrate density after fertilization decreased. Moreover, most of the metrics analyzed (Shannon, Simpson, and total density of macroinvertebrates) did not show a significant interaction between site and time throughout the study. These results indicate that neither diversity nor dominance and total macroinvertebrate density were affected by fertilization. This result contradicts our initial hypothesis that density and dominance of macroinvertebrates would increase in the reach under nutrient enrichment. In coincidence, SABATER et al. (2005) addressed that macroinvertebrate densities in the control reach of two mediterranean streams were similar to those in the impacted reach before an experimental fertilization took place and the observed effects were noticeable only for particular taxa. These authors found more significant variations for certain Oligochaeta and Mollusca species. In La Choza stream the selected treatment site also showed high dominance of oligochaete. However, after fertilization, the oligochaete density decreased significantly allowing greater representation of other taxa. According to ARMENDARIZ et al. (2012) a shift 
in Oligochaeta composition in favor of herbivores and detritivores and the replacement of sensitive species of the community could occur in nutrient-enriched systems, resulting in a greater tolerance of the overall population to environmental stress.

Our hypothesis about the taxa richness decreasing in the fertilized reach is rejected because after fertilization this metric has always been higher in the sites treated than in the control site. In this sense, McCormicK et al. (2004) did not register variations for species richness between control and fertilized sites in an experimental study carried out in Florida (USA). ARTIGAS et al. (2013) did not detect reduced species richness but a change in the dominance of taxa in favor of the more tolerant.

In La Choza stream, only 2 of 24 taxa of macroinvertebrates showed a response that could be attributable to fertilization. The enrichment favored taxa more tolerant to the new conditions and therefore increased their relative abundances. This was the case for $C$. fluminea and Ostracoda that increased their abundances, while Oligochaeta showed an increase but not sustained after addition. ARMENDÁRIZ et al. (2012) studied the response of Oligochaeta taxa but at family and species levels in the same lotic system. These authors found that abundance, biomass, diversity, evenness and richness increased significantly in the treatment site after fertilization in the sediments and in the aquatic vegetation, especially between Naidinae and Pristininae.

Corbicula fluminea increased significantly its abundance after fertilization. This clam is one of the most invasive species in freshwater aquatic ecosystems. The rapid growth, earlier sexual maturity, short life span, high fecundity and its association with human activities makes C. fluminea a non-indigenous invasive species likely to colonize new environments (Sousa et al., 2008). This adaptive advantage over the other species could generate a rapid response to changes in the environment caused by the nutrient addition. Moreover, $C$. fluminea is an important coupler between the water column and the stream sediments because this bivalve dominates filter-feeding in this stream and also pedal-feeding on buried organic material. OcóN et al. (2013) suggests that the increase in P concentration may have caused an increase in phytoplankton density on treatment site, making more resources available to filter feeders, which increased in proportion after fertilization. According to CoHEN et al. (1984), this species contributed to clarify the water bodies, thus decreasing the density of phytoplankton. Future studies are needed to explore the response of introduced species on the dynamics of the nutrients of the Pampean ecosystems.

MURKIN et al. (1994) found no significant differences in numbers, biomass of total invertebrates, and invertebrate functional groups in a similar experience in Canadian wetlands. These authors concluded that the nutrient additions did increase community productivity; however, the levels used in their study were insufficient to yield a sustained increase in primary or secondary productivity. According to Cross et al. (2007) the lack of a response of the macroinvertebrates assemblage could be due to the fact that a longer period of fertilization would be needed. These authors concluded that the effects on community composition require at least three years of continuous fertilization in order to be observed. However, effects could be seen in the short term when it comes to sensitive taxa, especially in environments with low nutrient concentration (SLAVIK et al., 2004; SABATER et al., 2011) or assemblages of primary producers (GómEz et al., 2009) and bacterial biomass (COCHERO et al., 2013) in euthrophic environments. Finally, ARTIGAS et al. (2013) showed that the pampean stream communities were less affected by enrichment than those of the Andean and Mediterranean streams despite wide windows of opportunity (periods when environmental constraints other than nutrients do not limit biomass growth).

In this study, the weak response of macroinvertebrates to fertilization in the pampean streams could be due to their tolerance to high concentrations of nutrients in accordance with their evolutionary history in streams naturally enriched with nutrients. We consider that in the Pampean streams the effect of nutrient enrichment may be less predictable in the short term due to their high basal nutrient concentration, in agreement with ARTIGAS et al. (2013). We suggest that further research should be focused on the study of the limits from which macroinvertebrates may be affected and on the adaptive advantage of taxa in naturally eutrophic environments. This information will allow for a better understanding of the processes of nutrient cycling and for the construction of restoration measures in natural eutrophic ecosystems.

Acknowledgments. This study was supported by BBVA Foundation's GlobRio Project and CONICET. This is Scientific Contribution $\mathrm{n}^{\circ} 946$ from the Instituto de Limnología "Dr. Raúl A. Ringuelet" (CONICET La Plata-UNLP). We wish to thank Mónica Caviglia for editing the final version of the manuscript.

\section{REFERENCES}

ACUÑA, V.; Vilches, C. \& Giorgi, A. 2011. As productive and slow as a stream can be: the metabolism of a Pampean stream. Journal of the North American Benthological Society 30:71-83.

APHA. 1998. Standard methods for the examination of water. 20ed. Washington D.C., American Public Health Association. 1134p.

Armendáriz, L.; Ocon, C. \& Rodrigues Capítulo, A. 2012. Potential responses of oligochaetes (Annelida, Clitellata) to global changes: Experimental fertilization in a lowland stream of Argentina (South America). Limnologica 42:118-126.

Artigas, J.; García Berthou, E.; Bauer, D. E.; Castro, M. I.; Cochero, J. ; Colautti, D.; Cortelezzi, A.; Donato, J.; Elosegi, A.; Feijoó, C.; Giorgi, A.; Gómez, N.; Leggieri, L.; Muñoz, I.; Rodrigues Capítulo, A.; Romaní, A. M. \& Sabater, S. 2013. Global pressures, specific responses: effects of nutrient enrichment in streams from different biomes. Environmental Research Letters 8:1-13.

Barbour, M. T.; Gerritsen, J.; Snyder, B. D. \& Stribling, J. B. 1999. Rapid bioassessment protocols for use in streams and wadeable rivers: periphyton, benthic macroinvertebrates and fish. 2 ed. Washington, D.C., U.S. Environmental Protection Agency, Office of Water. 197p.

Bauer, D. E.; Donadelli, J.; Gómez, N.; Licursi, M.; Ocon, C.; Paggi, A. C.; Rodrigues Capitulo, A. \& Tangorra, M. 2002. 
Ecological status of the Pampean plain streams and rivers (Argentina). Verhandlungen des Internationalen Verein Limnologie 28:259262.

Biggs, B. J. F.; Francoeur, S. N.; Huryn, A. D.; Young, R.; ArbuCKLE, C. J. \& Townsend, C. R. 2000. Trophic cascades in streams: effects of nutrient enrichment on autotrophic and consumer benthic communities under two different fish predation regimes. Canadian Journal of Fisheries and Aquatic Sciences 57:1380-1394.

Cabrera, A. L. 1976. Regiones Fitogeográficas Argentinas. 2ed. Enciclopledia Argentina de Agricultura y Jardinería. Tomo II, Fasc. 1. Buenos Aires, ACME. 85p.

Cochero, J.; Romaní, A. \& Gómez, N. 2013. Delayed response of microbial epipelic biofilm to nutrient addition in a Pampean stream. Aquatic Microbial Ecology 69:145-155.

Cohen, R. R. H; Dresler, P. V; Phillips, E. J. P. \& Cory, R. L.1984. The effect of the Asiatic clam, Corbicula fluminea, on phytoplankton of the Potomac River, Maryland. Limnolology \& Oceanography 29:170-180.

Cross, W. F.; Wallace, J. B. \& Rosemond, A. D. 2007. Nutrient enrichment reduces constraints on material flows in a detritus-based food web. Ecology 88:2563-2575.

Di Rienzo, J. A.; Casanoves, F.; Balzarini, M. G.; Gonzalez, L.; Tablada, M. \& Robledo, C. W. 2008. InfoStat, versión 2013. Córdoba, Grupo InfoStat, FCA, Universidad Nacional de Córdoba.

Dodds, W.; Bouska, W.; Eitzmann, J.; Pilger, T.; Pitts, K.; Riley, A.; Schoesser, J. \& Thornbrugh, D. 2009. Eutrophication of U.S. freshwaters: analysis of potential economic damages. Environmental Science and Technology 43:12-19.

Feijoó, C. S. \& Lombardo, R. J. 2007. Baseline water quality and macrophyte assemblages in Pampean streams: a regional approach. Water Research 41:1399-1410.

Feijoó, C. S.; Giorgi, A.; García, M. E. \& Momo, F. 1999. Temporal and spatial variability in streams of a pampean basin. Hydrobiologia 394:41-52.

Feijoó, C.; LegGieri, L.; Ocon, C.; Rodrigues Capítulo, A.; Giorgi, A.; Colautti, D.; Muñoz, I.; Ferreiro, N.; Licursi, M.; Gómez, N. \& SABATER, S. 2014. Stoichiometric homeostasis in the food web of a chronically nutrient-rich stream. Freshwater Science 33(3):820-831.

FERNÁNDEZ, H. \& DomínguEZ, E. eds. 2001. Guía para la determinación de los artrópodos bentónicos sudamericanos. San Miguel de Tucumán, EudeT (Serie Investigaciones de la UNT). 282p.

Ferreiro, N.; Giorgi, A.; Leggieri, L.; Feijoó, C. \& Vilches, C. 2011. Phosphorus enrichment affects immobilization but no litter decomposition or exoenzymatic activities in a Pampean stream. International Review of Hydrobiology 96:209-220.

Friberg, N.; Skriver, J.; Larsen, S. E.; Pedersen, M. L. \& Buffagni, A. 2010. Stream macroinvertebrate occurrence along gradients in organic pollution and eutrophication. Freshwater Biology 55:1405-1419.

Giorgi, A.; Feijoó, C. \& Tell, G. 2005. Primary producers in a Pampean stream: temporal variation and structuring role. Biodiversity and Conservation 14:1699-1718.

Gómez, N. \& Rodrigues Capítulo, A. 2001. Los bioindicadores y la salud de los ríos. In: Anales del V Seminario Internacional de Ingeniería y Ambiente. La Plata, Facultad de Ingeniería, Universidad Nacional de La Plata, p. 109-118.
Gómez, N.; Sierra, M. V.; Cochero, J.; Licursi, M. \& Bauer, D. 2009. Epipelic biofilms as indicators of environmental changes in lowland fluvial systems. In: BaILEy, W. ed. Biofilms: Formation, Development and Properties. Hauppage, Nova Science Publishers. $691 \mathrm{p}$.

Hulme, M. \& Sheard, N. 1999. Climate Change Scenarios for Australia. Available at $<\mathrm{http}: / / w w w . c r u . u e a . a c . u k>$. Accessed on May 2013.

Lin, L. \& WeBster, J. R. 2012. Sensitivity analysis of a pulse nutrient addition technique for estimating nutrient uptake in large streams. Limnology and Oceanography: Methods 10:718-727.

McCormick, P.; Shuford III, R. \& Rawlik, P. 2004. Changes in macroinvertebrate community structure and function along a phosphorus gradient in the Florida Everglades. Hydrobiologia 529:113-132.

Murkin, H.; Pollard, J.; Stainton, M.; Boughen, J. \& Titman, R. 1994. Nutrient additions to wetlands in the Interlake region of Manitoba, Canada: effects of periodic additions throughout the growing season. Hydrobiologia 279/280:483-495.

Ocón, C. S.; López van Oosterom, M. V.; MuÑoz, I. \& Rodrigues CApítulo, A. 2013. Macroinvertebrate trophic responses to nutrient addition in a temperate stream in South America. Fundamental and Applied Limnology 182:17-30.

Plafkin, J. L.; Barbour, M. T.; Porter, K. D.; Gross, S. K. \& Hughes, R. M. 1989. Rapid bioassessment protocols for use in streams and rivers. Benthic macroinvertebrates and fish. Available at $<\mathrm{http}: / /$ water.epa.gov/scitech/monitoring/rsl/bioassessment/>. Accessed on May 2014,

Robinson, C. T. \& GesSner, M. O. 2000. Nutrient addition accelerates leaf breakdown in an alpine springbrook. Oecologia 122:258-263.

Rodrigues Capítulo, A.; Gómez, N.; Giorgi, A. \& Feijoó, C. 2010. Global changes in Pampean lowland streams (Argentina): implications for biodiversity and functioning. Hydrobiologia 657:53-70.

Rodrigues Capítulo, A.; Muñoz, I; Bonada, N.; Gaudes, A. \& Tomanova, S. 2009. La biota de los ríos: los invertebrados. In: Elosegi, A. \& SABATER, S. eds. Conceptos y técnicas para el estudio de la ecología de ríos. Bilbao, Fundación BBVA, p. 248-264.

SAbater, S.; Acuña, V.; Giorgi, A.; GuAsch, H.; Guerra, E.; MuÑoz, I. \& Romaní, A. 2005. Assessing the ecological integrity after nutrient inputs in streams: the relevance of the descriptor and its associated scale. Aquatic Ecosystem Health \& Management 8:397-403.

Sabater, S.; Artigas, J., Gaudes, A.; Muñoz, I.; Urrea, G. \& Romani, A. 2011. Long-term moderate nutrient inputs enhance autotrophy in a forested Mediterranean stream. Freshwater Biology 56:1266-1280.

Salazar, R. H.; Luzzi, D. \& Lacoste, C. 1996. Cuencas Hídricas Contaminación, evaluación de riesgo y saneamiento. Buenos Aires, Instituto Provincial de Medio Ambiente. 184p.

Slavik, K.; Peterson, B.; Deegan, L.; Bowden, B.; Hershey, A. \& Hoвbie, J. 2004. Long-term responses of the Kuparuk River ecosystem to phosphorus fertilization. Ecology 85:939-954.

Sousa, R.; Antunes, C. \& Gulhermino, L. 2008. Ecology of the invasive Asian clam Corbicula fluminea (Muller, 1774) in aquatic ecosystems: an overview. Annales de Limnologie - International Journal of Limnology 44:85-94. 